\title{
Cambridge
}

\section{Geological Maps}

Their Solution and Interpretation

\section{T. BOLTON}

This illustrated textbook will aid all earth science students in geological map interpretation. It makes frequent reference to actual examples on which many of the problem maps are based. The text includes exercises on borehole interpretation and extensive worked solutions are given, making this an invaluable resource for teachers, lecturers and students.

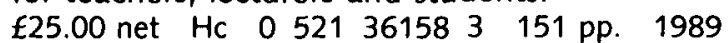

$£ 10.95$ net $\mathrm{Pb} \quad 0521367050$

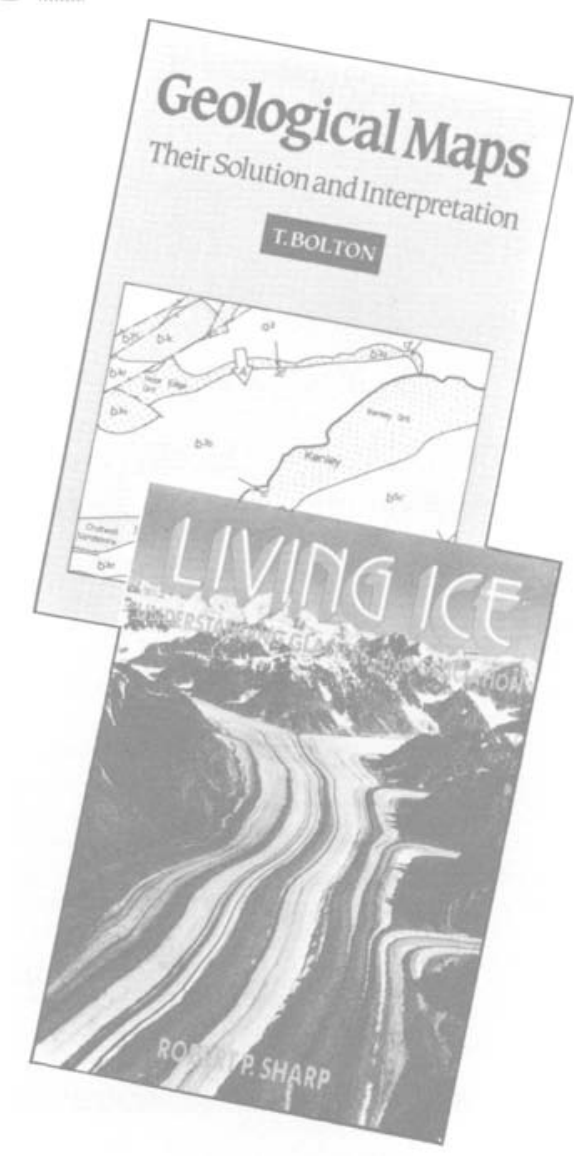

\section{Living Ice}

Understanding Glaciers and Glaciation ROBERT P. SHARP

Glaciers are complex, dynamical systems, sensitive to their surroundings and constantly changing shape and form. Robert Sharp explains the activity and effects of glaciers in non-technical language combining interesting facts with anecdotes and stunning illustrations.

$£ 15.00$ net 0521330092235 pp. 1989

\section{The Elements of Palaeontology}

\section{Second Edition}

\section{RHONA M. BLACK}

This thoroughly revised and updated textbook combines the beginners approach of the first edition with a depth and breadth of coverage ideal for those wishing to delve further. New features include trace fossils, microfossils, pollens and electron micrograph illustrations.

'.... a beautifully illustrated palaeontological textbook...' Nature

$£ 27.50$ net HC 0521343461415 pp. 1989

$£ 12.95$ net $\mathrm{Pb} \quad 0521348366$

\section{Now in paperback}

\section{The Beginning of the Age of Dinosaurs}

\section{Faunal Change Across the Triassic-Jurassic Boundary}

\section{KEVIN PADIAN}

Specialists examine the fauna, flora, climate, stratigraphic relationships and evolutionary changes of the time which saw dinosaurs develop and dominate the world.

$\therefore$... valuable to anyone interested in large-scale evolutionary problems. The debates (on the success of dinosaurs) will continue, but this volume provides a new benchmark from which they can proceed.'

f22.50 net $\mathrm{Pb} \quad 0521367794390 \mathrm{pp} .1989$

Journal of Geology

For further information please write to Jacqueline Arthurs at the address below

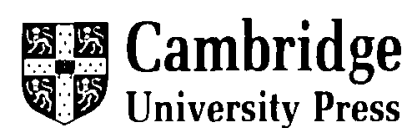

The Edinburgh Building, Cambridge CB2 2RU 


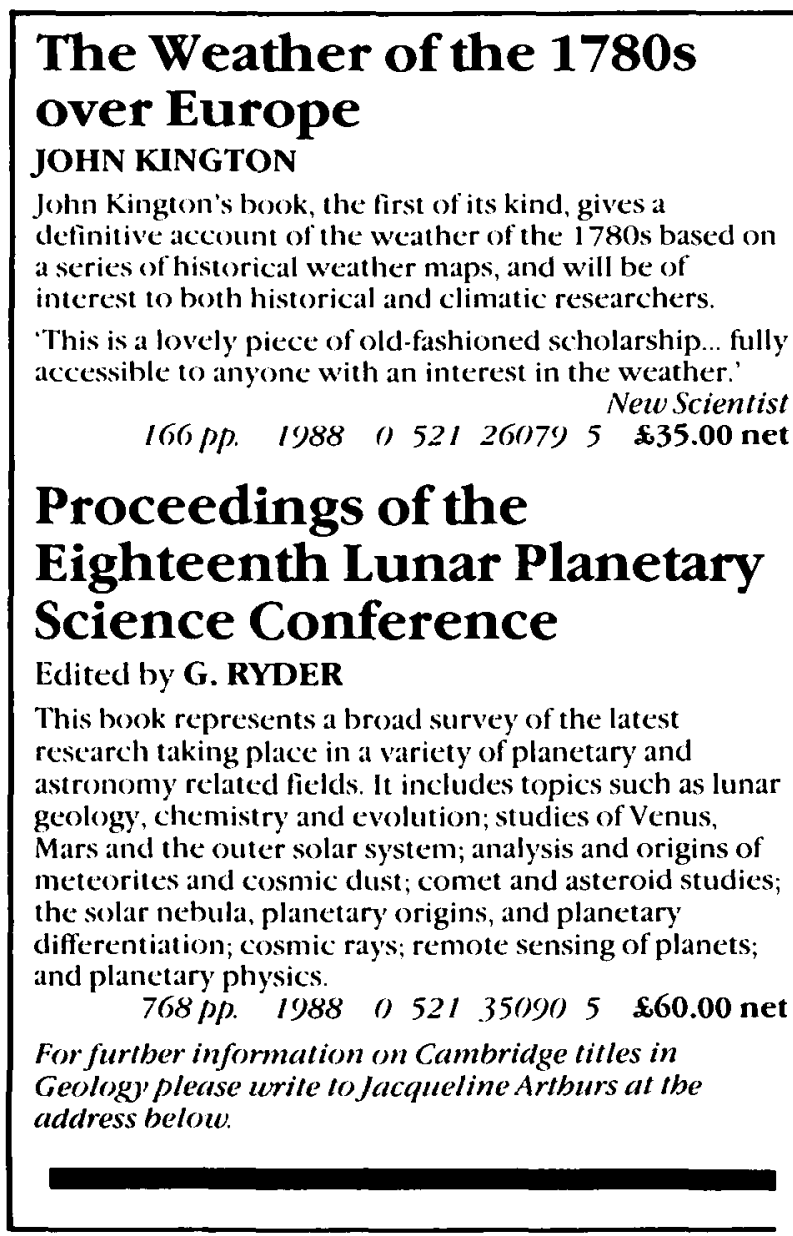

\section{Now in paperback \\ Thermoluminescence of Solids}

\section{S. W. S. MCKEEVER}

This book presents a unified approach to the topic of thermoluminescence and brings together the previously fragmented specialist approaches to the subject. It stresses the importance of the solid state aspects of the phenomenon and links these to applications in dating. dosimetry and geology

'... an excellent, critical introduction to the subject...'

Cambridge Solid State Science Series

$$
376 \text { pp. } 1988052136811 \text { l Pb\$17.50 net }
$$

\section{Drifting Continents and Shifting Theories}

The Modern Revolution in Geology and Scientific Change

\section{H. E. LE GRAND}

This innovative book uses the story of how the global theory of plate tectonics achieved its present shape and focus to introduce the question of the nature of scientific change and its philosophical analysis. The history of the rise to prominence of this theory is interwoven with reflective discussions of its context and the development of science more generally. $319 \mathrm{pP} \quad 1988 \quad 052132210.3$ Hc $\$ 30.00 \mathrm{net}$

\section{Cambridge University Press}

The Edinburgh Building, Shaftesbury Road, Cambridge CB2 2RU. 
Contributions for publication should be addressed to The Editors, Geological Magazine, Department of Earth Sciences, Downing Street, Cambridge CB2 3EQ, England, or may be submitted through a member of the Editorial Advisory Board (addresses inside front cover). Submission implies that the manuscript has not been published previously nor currently submitted for publication elsewhere.

All contributions, whether articles, correspondence or reviews, must be sent in triplicate and typed on one side of the paper, with wide margins and double-line spacing throughout. Any minor corrections should be made neatly in the typescript, leaving the margins clear. Contributions should follow the general style of papers in recent issues of the Magazine. The total length of a paper should not in general exceed 12 pages of the new A4 format of the Magazine, or 13000 word-equivalents. Priority may be given to short papers. The author is invited to nominate up to five possible referees, who will not necessarily be used.

Articles must be accompanied by a brief, informative rather than indicative, abstract. Headings should be set out clearly but not underlined. Primary headings should be in lower case, at margin, with arabic numeral; subheadings should be numbered 2.a., 2.b., etc., and tertiary headings 2.a.1., 2.a.2. No crossreferences should be given by page number, but 'above' and 'below' should be used with the section specified, e.g. Section 2.a.2. The SI system of units should be used. The author should mark in the margin of the manuscript where figures and tables may be inserted. References to points in larger works should, where possible, quote the page reference, e.g. Ager, 1981, p. 102.

Tables should be typed with double-line spacing on sheets separate from the running text. Each table must have a caption that will make the data in the table intelligible without reference to the text.

Illustrations should be prepared following the notes for guidance on the facing page. Duplicates of illustrations should be sent, and may be prints or. preferably, photocopies reduced to final size. Figures composed of photographs should be glossy prints presented at publication scale. Figure captions must be typed with double-line spacing on sheets separate from the running text.

The accuracy of references is the responsibility of authors. References must be double-spaced and spelt out in full, e.g.

BRoOKS, M. \& James, D. G. 1975. The geological results of seismic refraction surveys in the Bristol Channel, 1970-73. Journal of the Geological Society of London 131, 163-82.

Books should be cited as:

AgER, D. V. 1981. The Nature of the Stratigraphical Record, 2nd ed. London: Macmillan, $122 \mathrm{pp}$

Botт, M. H. P. 1973. The evolution of the Atlantic north of the Faroe Islands. In Implications of Continental Drift to the Earth Sciences, vol. 1 (eds. D. H. Tarling and S. N. Runcorn), pp. 175-89. London, New York: Academic Press.

Unpublished work should normally be referred to in the text in parentheses as, for example, "private communication' or 'unpub. Ph.D. thesis, Univ. London, 1988', and not included in the reference list unless in the press.

Fifty offprints of each paper will be provided free of charge. Additional offprints may be purchased according to a set scale of charges if ordered when the proofs are returned.

Back Volumes: Vols. 1-60 and 112 out of print. Vols. 61-111: Enquiries to Wm Dawson \& Sons Ltd, Cannon House, Folkestone, Kent. Volumes 113 onwards are available from Cambridge University Press.

\section{Copying}

This journal is registered with the Copyright Clearance Center, 27 Congress St., Salem, Mass. 01970. Organizations in the USA who are also registered with C.C.C. may therefore copy material (beyond the limits permitted by sections 107 and 108 of US copyright law) subject to payment to C.C.C. of the per-copy fee of $\$ 5.00$. This consent does not extend to multiple copy for promotional or commercial purposes. Code 0016-7568/ $89 \$ 5.00+.00$.

For all other use, permission should be sought from Cambridge or the American Branch of Cambridge University Press.

Claims for missing issues can only be considered if made immediately after receipt of the subsequent issue.

Advertising: Details of advertising in Geological Magazine may be obtained from the publisher. 


\section{Geological Magazine}

\section{Volume 126, Number 3, May 1989}

HARLEY. S. L.

The origins of granulites: a metamorphic perspective

Petrology and stratigraphy of some texturally well preserved thin komatiites from Kambalda, Western Australia

THOMSON, B.

$\mathrm{B}_{1}$ subdivisions in thin komatiites at Kambalda, Western Australia

SCHIEBER, J.

The origin of the Neihart Quartzite, a basal deposit of the Mid-Proterozoic Belt Supergroup, Montana, U.S.A.

HAMDI, B., BRASIER, M. D. \& JIANG ZHIWEN

Earliest skeletal fossils from Precambrian-Cambrian boundary strata, Elburz

Mountains, Iran

ORSZAG-SPERBER, F., ROUCHY. J. M. \& ELION, P.

The sedimentary expression of regional tectonic events during the Miocene Pliocene transition in the southern Cyprus basins

MORAD, S. \& VIDAL, G.

Proterozoic Mn-oxide precipitation by planktonic plant protists (acritarchs)

REVIEWS 